\title{
Prevalence of intestinal parasitic infections in preschool-children from vulnerable neighborhoods in Bogotá
}

\section{Prevalencia de parásitos intestinales en niños preescolares de barrios vulnerables de Bogotá}

\author{
Marlieke C.H. Bouwmans ${ }^{1}$, María Antonia Gaona ${ }^{2}$, Michelene N. Chenault ${ }^{1}$, Catalina Zuluaga ${ }^{2}$;
}

Ángela María Pinzón-Rondon ${ }^{2}$

\begin{abstract}
Suggested citation: Bouwmans MCH, Gaona MA, Chenault MN, Zuluaga C, Pinzón Rondón AM. Prevalence of intestinal parasitic infections in preschool-children from vulnerable neighborhoods in Bogotá. Rev Univ Ind Santander Salud. 2016; 48(2): 178-187. DOI: http://dx.doi.org/10.18273/revsal.v48n2-2016002 (c) (i) (
\end{abstract}

\begin{abstract}
Introduction: Intestinal parasitic infections (IPIs) are neglected tropical diseases, even though their prevalence is high in many developing countries. The public health impact of IPIs is substantial, in particular for children due to the negative effect on growth and development. Objectives: This study examines the prevalence and risk factors of IPIs in preschool-children from at-risk neighborhoods, including those from internally displaced families. Materials and Methods: A cross-sectional study among 239 preschool-children from two vulnerable neighborhoods in Bogotá. Fecal samples were collected and microscopically examined (direct and Ritchie technique) and data regarding related factors was obtained through a questionnaire. Results: A prevalence of $26.4 \%$ for pathogenic parasites (Giardia duodenalis, Blastocystis spp, Trichuris trichiura, Ascaris lumbricoides, and Hymenolepis nana) was found. Logistic regression resulted in four risk factors: siblings $\leq 5$ years (OR 2.33 [1.077-5.021]), stray dogs (OR 2.91 [0.867-9.767]), household members (OR 2.57 [1.155-5.706]) and child's sex (OR 2.17 [1.022-4.615]). Discussion: IPI presence in preschool children is an important health issue in Bogotá which should be addressed. A high protozoan prevalence was found compared to helminthes. Implementing policies addressing risk factors could be a first step in decreasing IPI prevalence.
\end{abstract}

Keywords: parasitic intestinal disease, preschool child, Colombia, human migration, cross sectional study.

\section{RESUMEN}

Introducción: Infecciones parasitarias intestinales (IPI) son enfermedades tropicales desatendidas, a pesar de que su prevalencia es alta en muchos países en desarrollo. El impacto en la salud pública de los IPI es importante, especialmente para los niños debido al efecto negativo sobre el crecimiento y el desarrollo. Objectivos: Este estudio examina la prevalencia y factores de riesgo de IPI en niños preescolares de barrios en riesgo, incluidos los de las familias desplazadas. Materiales y Métodos:

1. Maastricht University. Maastricht, The Netherlands

2. Universidad del Rosario. Bogotá, Colombia

Correspondence: Marlieke Bouwmans. Address: oranjeplein 90a, Maastricht (The Netherlands) E-mail: marliekebouwmans@, outlook.com Telephone: +31613179489 
estudio transversal entre 239 niños preescolares de dos barrios vulnerables de Bogotá. Se recogieron muestras fecales y se examinaron microscópicamente utilizando dos técnicas (directa y Ritchie). Se aplicó cuestionario para indagar factores relacionados con el parasitismo intestinal. Resultados: Se encontró una prevalencia de $26,4 \%$ de parásitos intestinales patógenos (Giardia duodenalis, Blastocystis spp, Trichuris trichiura, Ascaris lumbricoides y Hymenolepis nana). La regresión logística resultó en cuatro factores de riesgo: hermanos $\leq 5$ años (OR 2.33 [1.077-5.021]), los perros callejeros (OR 2.91 [0.867-9.767]), los ocupantes de la casa (OR 2.57 [1.155-5.706]) y el sexo del niño/a (OR 2.17 [1.022-4.615]). Discusión: La presencia del IPI en los niños preescolar es un problema de salud importante en Bogotá y que debe abordarse. Una alta prevalencia de protozoos se encontró comparado con helmintos. La implementación de políticas que aborden los factores de riesgo podría ser un primer paso en la disminución de la prevalencia del IPI. El antecedente de desplazamiento no cambio ni el tipo de parásito ni la prevalencia de parasitismo.

Palabras clave: Parasitosis intestinales, Preescolar, Colombia, Migración Interna, Estudios de corte transversal

\section{INTRODUCTION}

The Pan American Health Organization (PAHO) estimates that over one-third of the world population is infected with an intestinal parasite. In spite of this, many intestinal parasitic infections are still considered to be neglected tropical diseases ${ }^{1}$. 'Intestinal parasitic infections' (IPIs) is a collective term that includes infections caused by both helminths and protozoan. The highest prevalence of IPIs is generally found among school-aged children (SAC) ${ }^{1}$. Children are more vulnerable to severe consequences of these infections, due to the negative effect on growth and development ${ }^{1}$. Data about IPI prevalence in children in Colombia is limited, especially for the category of pre-school-aged children (PSAC). This impedes public health efforts in aiming at the appropriate (sub)population. Data about IPI prevalence in a region is essential for identifying local vulnerabilities and to adapt public health programs to this ${ }^{1}$. Insight into the risk factors for IPIs is important in order to tailor programs to local needs and circumstances.

\section{Parasite types}

Globally, a high prevalence is found for the helminths Ascaris lumbricoides (roundworm) and Trichuris trichiura (whipworm). Common pathogenic intestinal protozoan include Giardia duodenalis (intestinalis) and Entamoeba histolytica ${ }^{2}$. Blastocystis spp is also highly prevalent, but its pathogenicity is controversial ${ }^{3}$.

Pathogenic IPIs are often asymptomatic and thus go undiagnosed. This problem is amplified by the limited diagnostic value of traditional microscopy, due to a daily variation in egg excretion in feces ${ }^{4}$. Because of many undetected cases of IPIs, the magnitude of this health problem is difficult to estimate.

\section{Health consequences}

Negative consequences of IPIs in children include: reduced growth, reduced food intake, anemia and loss of iron, which has an impact on the child's physical, cognitive and overall societal development, even throughout adult life ${ }^{1,5}$. Additionally, there is a risk of acute complications; e.g. intestinal obstruction and rectum prolapse. Adequate treatment improves appetite, anthropometric measures and physical fitness ${ }^{5,6}$.

IPIs generally cause morbidity, rather than mortality. The World Health Organization (WHO) estimated in 2002 that the burden of Trichuris and Ascaris accounted for respectively 1.6 and 1.2 million lost Disability Adjusted Life Years (DALYs) ${ }^{7}$.

\section{Socio-economic factors}

Previous research established a relationship between IPI presence and socioeconomic factors 8 : low maternal education level, low family income, living in a rural area, poor sanitary facilities and sewage systems and limited access to healthcare services were associated with a higher IPI prevalence ${ }^{8-11}$.

In Colombia, the SISBEN-index is used as a representation of the socioeconomic status (SES) of a family. This index is a combination of variables (e.g. housing, use of public services, and demographics) used to assess a household's eligibility for social services. The Colombian population is ranked in strata from 1 to 6 . Most social programs, aiming at reducing (health) inequalities, only target strata 1 (extreme poverty) and 2 (poverty), The health insurance system in Colombia has a similar objective in offering two insurance arrangements: the subsidized regime (SR) for the poor and the contributing regime (CR) for wealthier families ${ }^{12}$. 


\section{IPIs in Colombia}

In Calarcá pathogenic IPIs were found in $42.7 \%$ of 220 PSAC $^{13}$, in the city of Armenia $24.1 \%$ of 328 children 1-7 years old was infected ${ }^{14}$, in Guapí the prevalence was $30.6 \%$ among 136 children $<2$ years of age ${ }^{15}$, while in Cali a staggering $84 \%$ of $57 \mathrm{SAC}$ from indigenous communities were IPI positive ${ }^{16}$. In most studies, $G$. duodenalis was the most prevalent intestinal parasite. The highest prevalence of potentially pathogenic parasites (88.9\%) was found in Medellín in a study among 58 children attending a feeding program ${ }^{17}$.

According to the WHO Colombia is a country with a moderate burden of soil-transmitted helminths; between $1 / 3 \mathrm{rd}$ and $2 / 3 \mathrm{rd}$ of (P)SAC are in need of treatment ${ }^{18}$. In 2009 about 1.5 million SAC received deworming treatment in Colombia, a coverage of approximately $29 \%{ }^{1}$. Unfortunately, these campaigns are not regularly organized, they are not aimed at PSACs, and no programs have been implemented to combat intestinal protozoan ${ }^{18}$. It is argued that solely focusing on treatment campaigns would be a mistake. Improving socio-economic determinants should be targeted as part of an eradication strategy ${ }^{19}$.

It is generally thought that IPIs are not an important health problem in Bogotá, because of the relative high level of economic development. However, this city has large income disparities and large peri-urban areas with poor living conditions. Approximately $44 \%$ of the population from Bogota is considered as being poor (SISBEN strata $1-2)^{20}$. Generally, the presence of IPIs is associated with living in a rural area because urban populations generally have better access to sanitation, clean water and health care services ${ }^{11}$. However, some researchers found the highest level of IPIs in peri-urban areas. They argue that urbanization increases IPI prevalence, if not accompanied by an increase in accessibility to basic infrastructure (e.g. sanitation and health care) $)^{21}$.

\section{Displacement}

A problem specific to Colombia is the huge numbers of internally displaced persons (IDPs), due to the country's history of violent conflict. This group is generally more vulnerable to health problems and offers an additional challenge to the health system of Colombia ${ }^{22}$. Therefore the IDPs are considered a separate category in this research.

Internal displacement in Colombia started to rise in the 1990s due to armed conflicts between the government and insurgent groups. An estimated 2.65-4.36 million people (5.7-9.3\% of the population) are internally displaced, ranking Colombia 2nd on a global scale ${ }^{23}$. The influx of IDPs to the cities has caused overcrowding and straining of the social system, since these displaced persons usually end up in the 'poverty belt'. There they continue to live in extremely poor circumstances; inadequate housing, limited access to healthcare, lower education for children and very low incomes ${ }^{22,23}$, increasing susceptibility to (parasitic) infections.

This research aims to investigate the prevalence of IPIs in PSAC living in vulnerable neighborhoods in Bogotá. In addition the prevalence of IPIs among internally displaced families and the factors associated with IPIs in this population will be examined. It is hypothesized that the scope of IPIs in Bogotá is much greater than previously thought and prevalence is higher among the displaced population.

\section{MATERIALS AND METHODS}

\section{Study design and population}

This cross sectional study was conducted between May and October 2013 in two neighborhoods in Bogotá: El Codito and Patio Bonito. Both are marginalized neighborhoods with typical characteristic of slums: lack of quality roads and public services, low education levels, poor housing conditions and high violence levels. Patio Bonito is home to many displaced families and is considered one of the most dangerous neighborhoods in Bogotá ${ }^{20,24}$.

The 239 PSAC (age 0-6 years) and their parents were approached through community daycare centers. The majority of these children belong to SISBEN-strata 1 or 2 , which is representative for the neighborhoods.

\section{Study procedures}

\section{Field Procedures}

Data collection included a feces sample and a questionnaire. The questionnaire addressed demographic factors: age, gender, household and environmental factors (e.g. housing, sanitation), behavioral factors (e.g. hygienic measures, recent antiparasitic treatment) and SES of the family (e.g. education, employment). In the case of illiteracy or a low reading proficiency of the parents, the questionnaire was administered orally by daycare teachers.

A plastic container and instructions for collection of a feces sample were given to the parents. They were 
instructed to bring the samples back to the daycare centers on the day of collection, preferably as soon as possible after the collection. A cool box with an ice pack was used to store and transport the samples to the laboratory on a daily basis to ensure the freshness of the samples.

\section{Laboratory procedures}

The feces samples were processed and analyzed at the Universidad del Rosario by experienced laboratory personnel on the day of collection. Subsequently, the samples were processed by means of the Ritchie procedure for concentration, using the formol-ether technique. These concentrated samples were examined again through microscopy. Only pathogenic parasites, including Blastocystis spp, were included in the data-analysis, because of their negative effect on children's health and development. The pathogenic E. histolytica was not included, because it is morphologically indistinguishable from the commensal E. dispar.

\section{Ethical considerations}

The study objectives and procedures were explained to the parents (primary caretaker). Verbal and written informed consent was obtained from both parents. Data was handled confidentially. The test results were returned to the primary caretaker. If pathogenic IPIs were found, a referral note for treatment was provided. If a family did not have access to treatment, it was provided to them. Additionally, all parents received a brochure with information about preventive measures for intestinal parasites. Approval was obtained from the Ethical Committee of the Universidad Del Rosario.

\section{Statistical analysis}

Data was processed and analyzed using IBM SPSS version 21. A descriptive analysis of the characteristics of the whole study population was performed, and for subgroups (family displaced less than five years ago, displaced and non-displaced -Taking into consideration that effects of migration depend on timing-). The prevalence of pathogenic IPIs was calculated. Possible risk factors were analyzed using crosstabs, chi-square tests and t-tests, and odds ratios and p-values were calculated. Factors that appeared to be significantly $(\mathrm{p}<0.10)$ associated with IPIs were analyzed further with multiple logistic regression (backwards method), to determine independent association. The displacement variable dichotomized (yes vs. no) and categorical (no, $<5$ years, $>5$ years) were added to all final models to review the effect of this factor, and all final models were also tested for interactions. The variable neighborhood was also added to the models but it was later remove because it did not improve the final model.

When the number of participants per category was too little, it was recoded into fewer categories, e.g. civil status was recoded from five into two categories: married/union libre (common law marriage) and single/widow/separated. To aid interpretation, continuous variables were converted into dichotomous variables, based on the median. Furthermore, a hygienic score was created, combining four variables involving (hand) washing behavior (after toilet use, before cooking, before feeding and washing of fruit/ vegetables). Based on the median two approximately equal groups were created, respectively considered as 'good' hygiene and 'moderate/poor' hygiene (Cronbach alpha: 0.642).

\section{RESULTS}

\section{Characteristics}

The final sample consisted of 239 children from whom stool samples were collected. For $98 \%$ of the cases questionnaires were (partially) completed. Almost 70\% of the samples were collected in El Codito. In Table 1 the characteristics of the total study population are shown, and per displacement category. The average age of the subjects is 36.6 months (s.d.15.9), the female-male ratio is 0.96 and the majority is Caucasian (50.5\%), closely followed by Mestizo (mixed European and Amerindian descent) (38.3\%). Most displaced families live in Patio Bonito (93.3\%).

Characteristics which showed a singnificant difference between displaced and non-displaced are: siblings below five (non-displaced $31.2 \%$ vs. displaced $54.2 \%$, $\mathrm{p}=0.002)$, paternal presence $(76.4 \%$ non-displaced vs. $62.7 \%$ displaced, $\mathrm{p}=0.043$ ), civil status of parents (married/union libre: $78.3 \%$ non-displaced vs. $61.7 \%$ displaced, $\mathrm{p}=0.013$ ), education level of mother (only primary education: non-displaced $14.0 \%$ vs. displaced $43.4 \%, \mathrm{p}=0.000)$, access to healthcare as perceived by the parents (non-displaced 91.5\%, displaced $76.5 \%, \mathrm{p}=0.005$ ) and insurance regime (subsidized/ no insurance: non-displaced: $57.1 \%$, displaced $77.6 \%$, $\mathrm{p}=0.012$ ). 
Table 1. Characteristics of study population, displaced and non-displaced

\begin{tabular}{|c|c|c|c|c|}
\hline Characteristics & $\begin{array}{c}\text { Displaced } \\
\%(n)\end{array}$ & $\begin{array}{c}\text { Displaced } \\
\leq 5 y \\
\%(n)\end{array}$ & $\begin{array}{c}\text { Non- } \\
\text { displaced } \\
\%(n)\end{array}$ & $\begin{array}{l}\text { Total } \\
\text { group } \\
\%(n)\end{array}$ \\
\hline \multicolumn{5}{|l|}{ Neighborhood $(\%)^{*}$} \\
\hline - El Codito & $6.7(4)$ & $0.0(0)$ & $89.5(145)$ & $69,5(166)$ \\
\hline - Patio Bonito & $93.3(56)$ & $100.0(29)$ & $10.5(17)$ & $30,5(73)$ \\
\hline \multicolumn{5}{|l|}{ Persons in household* } \\
\hline - 1-4 persons* & $46.7(28)$ & $51.7(15)$ & $61.5(99)$ & $56.3(130)$ \\
\hline-5 or more persons & $53.3(32)$ & $48.3(14)$ & $38.5(62)$ & $43.7(101)$ \\
\hline \multicolumn{5}{|l|}{ Siblings $\leq 5$ yrs* } \\
\hline - Yes & $54.2(32)$ & $53.6(16)$ & $31.2(48)$ & $39.0(87)$ \\
\hline - No & $45.8(27)$ & $46.4(13)$ & $68.8(106)$ & $61.0(136)$ \\
\hline \multicolumn{5}{|l|}{ Parental presence $(\%)$} \\
\hline - Mother & $96.6(57)$ & $100.0(28)$ & $97.5(158)$ & $97.4(225)$ \\
\hline - Father* & $62.7(37)$ & $60.7(17)$ & $76.4(123)$ & $73.0(168)$ \\
\hline \multicolumn{5}{|l|}{ Civil status $(\%)^{*}$} \\
\hline - Single/alone & $38.3(23)$ & $44.8(13)$ & $21.7(35)$ & $26.0(60)$ \\
\hline - Married/union libre & $61.7(37)$ & $55.2(16)$ & $78.3(126)$ & $74.0(171)$ \\
\hline \multicolumn{5}{|l|}{ Family income (\%) } \\
\hline$-<\min$. wage $(\$ 589.500)$ & $61.1(33)$ & $74.1(20)$ & $58.0(83)$ & $59.8(122)$ \\
\hline - $1-2 x$ minimal wage & $38.9(21)$ & $25.9(7)$ & $42.0(60)$ & $40.2(82)$ \\
\hline \multicolumn{5}{|l|}{ SISBEN-status } \\
\hline-1 & $58.6(17)$ & $71.4(10)$ & $54.0(67)$ & $55.6(89)$ \\
\hline-2 or 3 & $41.4(12)$ & $28.6(4)$ & $46.0(57)$ & $44.4(71)$ \\
\hline \multicolumn{5}{|l|}{ Insurance type* } \\
\hline - Subsidized/uninsured & $77.6(38)$ & $80.0(20)$ & $57.1(76)$ & $63.7(121)$ \\
\hline - Contributing regime & $22.4(11)$ & $20.0(5)$ & $42.9(57)$ & $36.3(69)$ \\
\hline \multicolumn{5}{|l|}{ Access to healthcare* } \\
\hline - Yes & $76.5(39)$ & $69.6(16)$ & $91.5(130)$ & $86.7(176)$ \\
\hline - No & $23.5(12)$ & $30.4(7)$ & $8.5(12)$ & $13.3(27)$ \\
\hline \multicolumn{5}{|l|}{ Education mother $(\%)^{*}$} \\
\hline$-\leq$ primary school & $43.4(23)$ & $48.0(12)$ & $14.0(20)$ & $22.9(47)$ \\
\hline - Secondary + media & $52.8(28)$ & $52.0(13)$ & $69.9(100)$ & $64.9(133)$ \\
\hline - Tertiary & $3.8(2)$ & $0.0(0)$ & $16.1(23)$ & $12.2(25)$ \\
\hline
\end{tabular}

* Significant difference $(\mathrm{p}<0.05)$ between displaced and nondisplaced population

\section{Parasite prevalence and risk factors}

Pathogenic IPIs were found in $26.4 \%$ of the samples (95\% CI 20.5\% - 31.8\%), with G. duodenalis having the highest prevalence (15.1\%) (Table 2). In 7 children there was poly-parasitism, of which two had a combination of helminths and protozoan. Potential factors related to IPI presence were divided into three categories: household and child characteristics, environmental, and behavioral. Table 3 presents some of these characteristics along with prevalence rates of pathogenic IPIs per subgroup and ORs for IPIs.

Table 2. Prevalence of intestinal parasites in the study population

\begin{tabular}{lc}
\hline Pathogen & Prevalence \% (n), [95\% CI] \\
\hline All pathogenic parasites & $26.4(63)^{*},[20.5-31.8]$ \\
Giardia duodenalis & $15.1(36),[10.5-19.7]$ \\
Blastocystis spp & $9.6(23),[5.9-13.4]$ \\
Trichuris trichiura & $2.1(5),[0.4-4.2]$ \\
Ascaris lumbricoides & $1.3(3),[0.0-2.5]$ \\
Hymenolepis nana & $1.7(4),[0.4-3.3]$ \\
\hline
\end{tabular}

* Because of polyparasitism this number does not correspond with the sum of the separate pathogenic parasites.
Factors associated with the presence of IPIs were: mother with a low level job (manual labor) or who stayed at home ( $28 \%$ vs. $0 \%$ in high level jobs), a large household size (OR: 2.47 [1.34-4.54], $\mathrm{p}=0.003$ ), siblings below five, (OR: 2.86 [1.53-5.34], $\mathrm{p}=0.001$ ), low SISBEN-status (OR: 2.52 [1.22-5.19], $\mathrm{p}=0.011$ ), and subsidized insurance/no insurance (OR: 2.60 [1.205.63], $\mathrm{p}=0.013$ ). No significant relationship was found between IPIs and age, sex, ethnicity, family income, education of the mother or displacement status.

Environmental factors significantly associated with IPIs in the study population are: stray dogs around the house (OR: 3.61 [1.32-9.87], $\mathrm{p}=0.012$ ) and room crowding (OR: 2.34 [1.25-4.39], $\mathrm{p}=0.007$ ). No significant relationship was found between pathogenic IPIs and access to public services (electricity, aqueduct, sewage, and garbage disposal), a private or shared toilet, or the house type (own/rented).

None of the behavioral characteristics were found to be significantly associated with IPIs. There was also no significant relationship between the hygienic score and IPI presence.

The examination of these characteristics only in the displaced population did not result in any additional risk factors for IPIs.

\section{Logistic regression}

The factors which were found to be significantly associated (at a significance level of 0.10 ) to the presence of IPIs were: SISBEN status, health insurance, siblings below five, household size, stray dogs, profession and education of the mother, sex, garbage disposal, floor material, and room crowding. Since the SISBEN-status and the health insurance are aggregates of socio-economic indicators and thus strongly correlated with household size and education, they were not included in the model. The profession of the mother was also excluded from the model since the low number of mothers with a technical/ professional job $(\mathrm{n}=19)$ precluded estimation for this item. Garbage disposal was left out of the model because of missing values of $41.4 \%$.

The backward selection procedure resulted in a model with four explanatory variables: siblings below five, stray dogs, female sex, and a large household size (Table 4). The inclusion of displacement status in the model did not alter the model so that it could be concluded that displacement was not a confounder. Furthermore there are no significant interaction terms between displacement status and these four factors. 
Salud Vol.48 No.2 Abril - Junio de 2016

DOI: http://dx.doi.org/10.18273/revsal.v48n2-2016002

Table 3. Descriptives of child/household characteristics together with prevalence, ORs and significance levels for presence of IPIs

\begin{tabular}{lcccc}
\hline Characteristics & $\%(n)$ of study sample & $\begin{array}{c}\text { subgroup with IPI, } \\
\%(n)\end{array}$ & $\begin{array}{c}\text { Subgroup without IPI } \\
\%(n)\end{array}$ & OR [95\% C.I.] \\
\hline Child and household & & &
\end{tabular}

Sex

- Female

- Male

Neighborhood

- El Codito

- Patio Bonito

Displaced

- Not displaced

- Yes, total group

- $<5$ years

Max. education mother

- s primary

- Secondary + media

- Tertiary

Profession mother

- At home/unemployed

- Manual work

- Tech/prof job

\# of persons in household

- 1-4 persons

- 5 or more persons

Presence of siblings $\leq \mathbf{5 y}$

- Yes

- No

SISBEN

$-1$

- 2 or 3

Healthcare insurance

- Subsidized/uninsured

- Contributing regime

$\begin{array}{cc}49.1(114) & 30.7(35) \\ 50.9(118) & 21.2(25) \\ 69.5(166) & 28.9(48) \\ 30.5(73) & 20.5(15) \\ 73.0(162) & 25.9(42) \\ 27.0(60) & 21.7(13) \\ 13.2(29) & 31.0(9) \\ & \\ 22.9(47) & 27.7(13) \\ 64.9(133) & 27.8(37) \\ 12.2(25) & 12.0(3) \\ & \\ 45.3(102) & 28.4(29) \\ 46.2(104) & 27.9(29) \\ 8.4(19) & 0(0) \\ & \\ 56.3(130) & 17.7(23) \\ 43.7(101) & 34.7(35) \\ & \\ 39.0(87) & 36.8(32) \\ 61.0(136) & 16.9(23) \\ & \\ 55.6(89) & 38.2(34) \\ 44.4(71) & 19.7(14) \\ & \\ 63.7(121) & 30.6(37) \\ 36.3(69) & 14.5(10) \\ & \\ & \\ & \\ & \\ & \\ & \\ & \\ & \\ & \end{array}$

$69.3(79)$

$78.8(93)$

$71.1(118)$

$79.5(58)$

$74.1(120)$

$78.3(47)$

$69.0(20)$

$72.3(34)$

$72.2(96)$

$88.0(22)$

$71.6(73)$

$72.1(75)$

100 (19)

$82.3(107)$

$65.3(66)$

$63.2(55)$

$83.1(113)$

$61.8(55)$

$80.3(57)$

$69.4(84)$

$85.5(59)$
NS

NS

NS

NS

$\mathrm{p}=0.027$

$\mathrm{p}=0.003$

2.47 [1.34-4.54]

$\mathrm{p}=0.001$

2.86 [1.53-5.34]

$\mathrm{p}=0.011$

2.52 [1.22-5.19]

$\mathrm{p}=0.013$

2.60 [1.20-5.63]

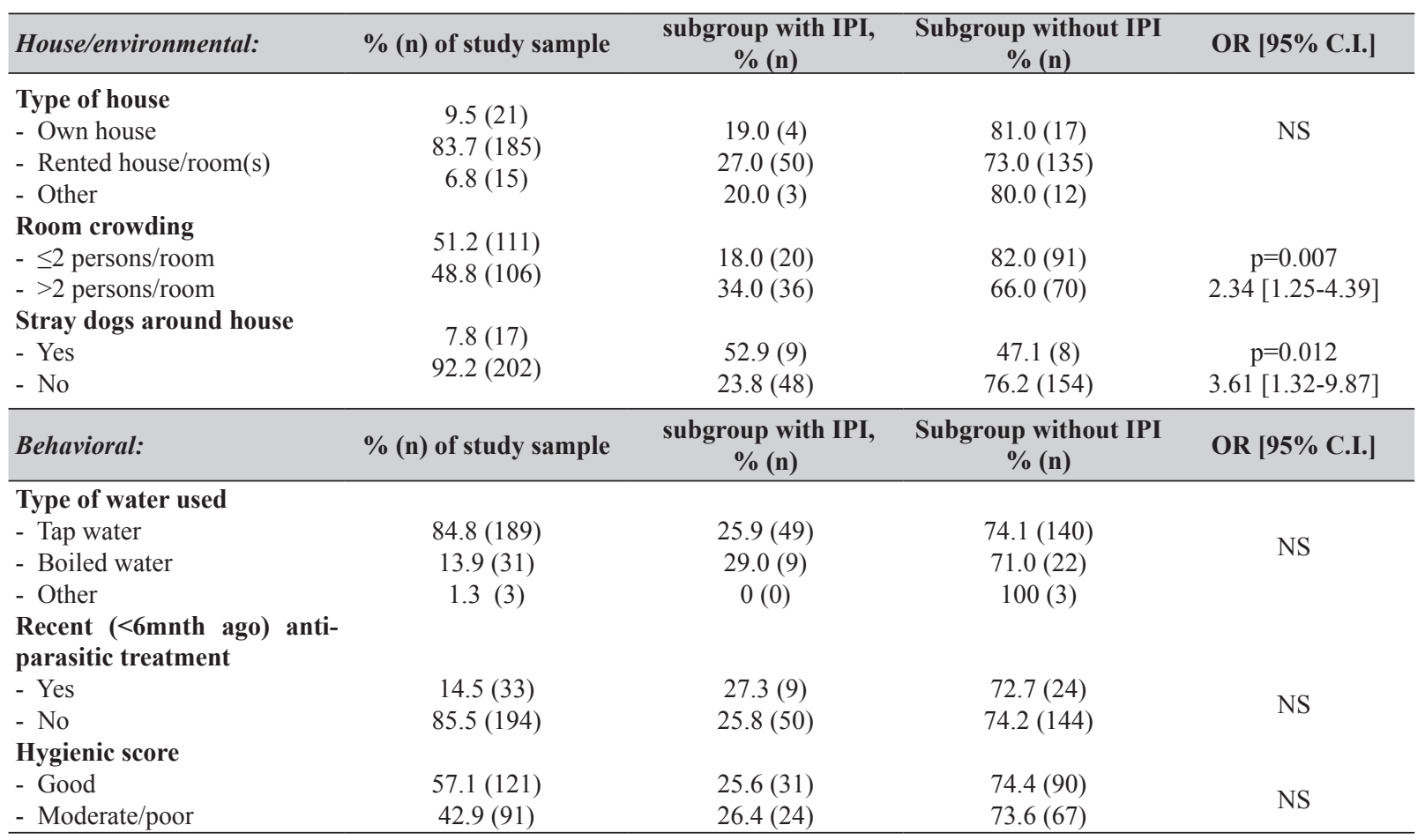


Table 4. Log. Regression model (coefficients and ORs) resulting from backward selection procedure for outcome pathogenic IPIs.

\begin{tabular}{lccccc}
\hline & b & se & Wald & Sig. & Odds ratio [95\% C.I.] \\
\hline Constant & -2.526 & 0.426 & 35.222 & 0.000 & 0.080 \\
Presence of siblings $\leq \mathbf{5}$ yrs & 0.844 & 0.393 & 4.617 & 0.032 & $2.325[1.077-5.021]$ \\
Stray dogs & 1.068 & 0.618 & 2.988 & 0.084 & $2.910[0.867-9.767]$ \\
Sex (female) & 0.775 & 0.385 & 4.063 & 0.044 & $2.171[1.022-4.615]$ \\
Household size (categorical) & 0.943 & 0.407 & 5.354 & 0.021 & $2.567[1.155-5.706]$ \\
\hline
\end{tabular}

\section{DISCUSSION}

The low mortality rates and the mainly long term consequences of IPIs explain the lack of priority assigned to them. To adequately tackle the problem of IPIs, through treatment campaigns or social policies, it is important to have accurate prevalence estimates and a clear picture of which factors are related to IPIs. This is important for evidence-based policy at a (sub)national level to tailor health programs to local needs and to monitor and evaluate the impact of implemented programs.

\section{Prevalence of pathogenic intestinal parasites}

The $26.4 \%$ prevalence of pathogenic IPIs found in our study population is lower than that found by many other studies which have been conducted in Colombia ${ }^{13,16,25,26}$ that reported prevalence rates varying between $42.7 \%$ and $89.7 \%$. These studies were conducted in varying contexts; rural-urban, low-high SES and among indigenous communities. The national survey about morbidity (1980) reported that pathogenic parasites are less frequent in the Bogotá area as compared to other areas of Colombia ${ }^{14}$. Nevertheless, the hypothesis that IPIs are also an important health problem in Bogotá is confirmed by our results, hereby rendering IPIs a relevant health issue in Bogotá.

Low prevalence rates were found for intestinal helminths; $2.1 \%$ for $T$. trichiura, $1.3 \%$ for $A$. lumbricoides, and $1.7 \%$ for $H$. nana. Comparably low prevalence rates $(0.6 \%$ $2.4 \%$ ) were found in other areas in Colombia ${ }^{13,14,25}$. However, some research in Colombia has revealed that there is a much higher prevalence for helminths in some areas, varying from $16.7 \%$ to $26.2 \%{ }^{10,15,16}$. Over the past decades, urban areas have shown a decline in intestinal helminths, probably due to improvements in sanitation and general living conditions ${ }^{26}$. This could explain the low helminthic prevalence in our sample where $86.9 \%$ of households have an aqueduct, $87.4 \%$ a sewage, and $82.7 \%$ a private toilet.

The prevalence for $G$. duodenalis (15.1\%) is comparable to previous studies in Colombia which found prevalences of 7.8\%-11.6\% in $\mathrm{SAC}^{25,27}$ and 13.0-
$16.5 \%$ in PSAC ${ }^{13,14,26}$. The prevalence of Blastocystis spp in Colombia varies greatly; $1.7 \%{ }^{10}$ to $67.9 \%{ }^{25}$. No explanations are provided for this wide range of prevalence figures, making comparisons for Blastocystis spp difficult. The $9.6 \%$ prevalence found in our sample falls within this broad range.

\section{Internally displaced persons}

IDPs generally have a low SES and increased health risks ${ }^{28}$; therefore it was hypothesized that IPI prevalence was higher in this population. Many socioeconomic characteristics were significantly different between the displaced and non-displaced population, however, this did not result in a significant effect on IPI prevalence. The highest IPI prevalence was found among the displaced population $\leq 3$ years; $35.5 \%$ vs. $25.9 \%$ in non-displaced (non-significant). This may be because (socioeconomic) differences in IDPs normalize over time. Only a small number of recently displaced families ( $n=29$ for displacement $\leq 5$ years) were recruited for this study precluding the possibility of drawing clear conclusions regarding this.

\section{Risk factors for IPIs}

As expected, the SISBEN-status and the health insurance were found to be associated with IPIs. After excluding these variables from the regression analysis due to collinearity issues, four variables remained which together were associated with the presence of pathogenic IPIs: siblings below five, large household size, stray dogs, and sex.

\section{Siblings below five and household size}

Large households are often thought to increase IPI risk due to overcrowded conditions ${ }^{17,29}$. However, the variable 'room crowding' did not remain significantly associated with IPIs after logistic regression. This is probably partly due to a medium correlation between these two variables (Phi coefficient of $0.55, p=0.00$ ).

Previous research in Colombia found a similar relationship between having siblings below five and 
IPIs. Children are more frequently infected with IPIs ${ }^{1}$, and intensive contact between siblings can result in a higher transmission risk.

\section{Stray dogs}

Previous research has found that dogs are a reservoir for intestinal parasites, and inadequate parasite control in dogs can increase IPI prevalence in children ${ }^{13}$. Many recreational areas in Bogotá are polluted with parasites present due to dog excrements ${ }^{30}$. In Bogotá there is an abundance of stray $\operatorname{dog}^{31}$. In this research only a trend is observed -probably due to the sample size- that suggests an association between stray dogs and IPIs $(p=0.084$, CI 0.867-9.767). A strategy to reduce IPI prevalence could therefore be an increased focus on parasite control in animals (pets and stray dogs) ${ }^{13}$.

\section{Sex of the child}

In this study, girls appear to be more at risk for IPIs. Previous research has yielded contradicting results in this regard; In Teheran (Iran) a significantly higher IPI prevalence was found among girls ${ }^{32}$, while in Sudan this was the case for boys ${ }^{33}$. Also in Colombia a higher prevalence of Giardia in (pre)school boys was found by some researchers ${ }^{15,34}$. Generally, studies in Colombia found no difference between boys and girls ${ }^{10,13,14,35}$. A satisfactory explanation for the higher IPI prevalence among girls in this sample is not available.

\section{Remaining factors}

Behavioral characteristics were not significantly associated with IPIs. This should be interpreted with caution since participants may not have been completely honest when answering these questions, especially because they often received help from the daycare teacher when filling in the questionnaire. No additional risk factors were found for the displaced population, possibly due to the limited number of displaced participants.

\section{Limitations and weaknesses}

Limitations of this study lie in its design; crosssectional research only provides information about a single point in time, thereby precluding the conclusions about causation. Data collection through daycare centers is also a potential limitation, because some populations of at risk children may not attend daycare. However, as explained by teachers it is common for all PSAC to go to a daycare center, even when they are from the most marginalized families. Another point to consider is the fact that daycare centers are often overcrowded so that children could easily contaminate each other due to the combination of less than optimal hygienic behavior and the crowded circumstances. During the sample processing Giardia appeared to be highly prevalent in some daycare centers. This parasite is known to occur in (small) outbreaks ${ }^{36}$. Unfortunately there were no questions addressing the characteristics of the day care centers, which potentially may contribute to IPI prevalence. Finally, the study did not include the child's gastrointestinal symptoms, which could have told more about the implications of the intestinal parasite infections. However, the age of the children made the inclusion of symptoms very difficult.

\section{CONCLUSION}

The WHO advises regular deworming campaigns in Colombia $^{18}$. This is not in line with the results of this research; a low prevalence of helminths, and a much higher prevalence for protozoan was found. Because of the considerable differences in helminthic prevalence in Colombia, and because of the high protozoan prevalence, regular coprological examination for (P)SAC may be a better approach. Because of the high transmission risk among siblings, diagnosis and treatment of the 'core family' of infected persons could help to prevent reinfection within the family ${ }^{13}$.

The presence of pathogenic IPIs is greatly influenced by socioeconomic factors. These factors are often intertwined and slow to change (e.g. economic inequalities, violent conflict) and thus do not render quick solutions ${ }^{19}$. Nevertheless, these factors must be considered to effectively decrease IPI prevalence in the long term. In the meantime, other measures should be taken: regular coprological examination, control strategies for parasites in dogs, examination and treatment of the core family, and health education.

Research on a larger and recently displaced population could help in understanding the effect of displacement (duration) on IPI presence.

\section{ETHICAL CONSIDERATIONS}

Ethical approval was given by the: Comité de Ética en Investigaciones (CEI) Escuela de Medicina y Ciencias de la Salud de la Universidad del Rosario

\section{CONFLICT OF INTEREST}

There are no conflicts of interest to report. 


\section{REFERENCES}

1. Saboyá M, Catalá L, Ault S, Nicholls R. Prevalence and intensity of infection of Soil-transmitted Helminths in Latin America and the Caribbean Countries: Mapping at second administrative level 2000-2010. Pan American Health Organization. 2011.

2. Haque R. Human intestinal parasites. J Health Popul Nutr. 2007; 25(4): 387-91.

3. Tan KS. New insights on classification, identification, and clinical relevance of Blastocystis spp. Clin Microbiol Rev. 2008; 21(4): 639-665. DOI: 10.1128/CMR.00022-08.

4. Tarafder MR, Carabin H, Joseph L, Balolong E Jr, Olveda R, McGarvey ST. Estimating the sensitivity and specificity of Kato-Katz stool examination technique for detection of hookworms, Ascaris lumbricoides and Trichuris trichiura infections in humans in the absence of a 'gold standard'. Int J parasitol. 2010; 40(4): 399-404. DOI: 10.1016/j. ijpara.2009.09.003.

5. Stephenson LS, Latham MC, Ottesen EA. Malnutrition and parasitic helminth infections. Parasitology. 2000; 121(S1): S23-S38. DOI: 10.1017/S0031182000006491.

6. Carvalho-Costa FA, Gonçalves AQ, Lassance SL, Neto S, Salmazo CAA, Bóia MN. Giardia lamblia and other intestinal parasitic infections and their relationships with nutritional status in children in Brazilian Amazon. Rev Inst Med Trop Sao Paulo. 2007; 49(3): 147-153.

7. World Health Organization. The World health report: 2002: Reducing the risks, promoting healthy life. 2002. p. Annex Table 3; 196-197.

8. Okyay P, Ertug S, Gultekin B, Onen O, Beser E. Intestinal parasites prevalence and related factors in school children, a western city sample-Turkey. BMC Public Health. 2004; 4(1): 64. DOI: 10.1186/14712458-4-64.

9. Quihui L, Valencia ME, Crompton DW, Phillips S, Hagan P, Morales G, et al. Role of the employment status and education of mothers in the prevalence of intestinal parasitic infections in Mexican rural schoolchildren. BMC Public Health. 2006; 6(1): 225. DOI: 10.1186/1471-2458-6-225.

10. Botero-Garcés JH, García-Montoya GM, GrisalesPatiño D, Aguirre-Acevedo DC, Álvarez-Uribe MC. Giardia intestinalis and nutritional status in children participating in the complementary nutrition program, Antioquia, Colombia, May to October 2006. Rev Inst Med Trop São Paulo. 2009; 51(3): 155-162. DOI: 10.1590/S0036-
46652009000300006.

11. de Oliveira Pinheiro I, de Castro MF, Mitterofhe A, Pires FAC, Abramo C, Ribeiro LC, et al. Prevalence and risk factors for giardiasis and soil-transmitted helminthiasis in three municipalities of Southeastern Minas Gerais State, Brazil. Parasitol Res. 2011; 108(5): 1123-1130. DOI: $10.1007 / \mathrm{s} 00436-010-$ 2154-X .

12. Vélez CE, Castaño E, Deutch R. An economic interpretation of Colombia's SISBEN: a composite welfare index derived from the optimal scaling algorithm. Washington D.C.: World Bank; 1998.

13. Londoño AL, Mejia S, Gomez-Marín JE. Prevalence and risk factors associated with intestinal parasitism in preschool children from the urban area of Calarcá, Colombia. Rev Salud Publica (Bogota). 2009; 11(1): 72-81. DOI: 10.1590/S0124-00642009000100008.

14. Giraldo-Gómez JM, Lora F, Henao LH, Mejía S, Gómez-Marín JE. Prevalence of giardiasis and intestinal parasites in pre-school children from homes being attended as part of a state programme in Armenia, Colombia. Rev Salud Publica (Bogota). 2005; 7(3): 327-338. DOI: 10.1590/S012400642005000300008 .

15. Alvarado BE, Vasquez LR. Social determinants, feeding practices and nutritional consequences of intestinal parasitism in young children. Biomedica. 2006; 26(1): 82-94. DOI: 10.7705/biomedica. v26i1.1397.

16. Salcedo-Cifuentes M, Florez O, Bermudez A, Hernandez L, Araujo C, Bolanos MV. Intestinal parasitism prevalence amongst children from six indigenous communities residing in Cali, Colombia. Rev Salud Publica (Bogota). 2012; 14(1): 156-168. DOI: $10.1590 / \mathrm{S} 0124-00642012000100013$.

17. Medina Lozano A, García Montoya G, Galván Díaz AL, Botero Garcés J. Prevalencia de parásitos intestinales en niños que asisten al Templo Comedor Comedor Sagrado Corazón Teresa Benedicta de la Cruz, del barrio Vallejuelos-Medellín, 2007. Iatreia. 2009; 22(3): 227-234.

18. World Health Organization. Soil-transmitted helminthiases: eliminating as public health problem soil-transmitted helminthiases in children: progress report 2001-2010 and strategic plan 2011-2020. Geneva; 2012. p. 42-48.

19. Godlee F. Treat the worms, but do other things too. BMJ: British Medical Journal. 2013; 346. DOI: 10.1136/bmj.e8721

20. Rueda-García N. Urban Slums Reports: The case of Bogotá, Colombia. Global Report on Human Settlements 2003, The Challenges of Slums Part IV: Summary of City Case Studies. London: UN- 
Habitat; 2003. p. 195-228.

21. Zonta ML, Navone GT, Oyhenart EE. Parasitosis intestinales en niños de edad preescolar y escolar: situación actual en poblaciones urbanas, periurbanas y rurales en Brandsen, Buenos Aires, Argentina. Parasitol latinoam. 2007; 62(1-2): 54-60. DOI: $10.4067 / \mathrm{S} 0717-77122007000100009$.

22. Carrillo AC. Internal displacement in Colombia: humanitarian, economic and social consequences in urban settings and current challenges. Int Rev Red Cross. 2009; 91(875): 527-546. DOI: 10.1017/ S1816383109990427.

23. Albuja S, Beau C, Birkeland N, Dolores R, Halff $\mathrm{K}$, Khalil K, et al. Internal Displacement. Global Overview of Trends and Development in 2008. Internal Displacement Monitoring Centre Geneva; 2009. p. 13-5, 91-2.

24. Mendoza E. Trabajo Infantil en la Central de Abastos de Bogotá, Corabastos. Diagnóstico General de la Situación. In: Departamento Administrativo de Bienestar Social, editor. Programa de acción para la prevención y la erradicación del trabajo infantil en la central de abastos de Bogotá, Corabasto. Bogotá: Organización Internacional del Trabajo (OIT) and International Programme on the Elimination of Child Labour (IPEC); 2004.

25. Manrique Abril FG, Suescún Carrero SH. Prevalencia de parasitismo intestinal y situación nutricional en escolares y adolescentes de Tunja. CES Med. 2011; 25(1): 20-30.

26. Arias JA, Guzmán GE, Lora-Suárez FM, Torres E, Gómez JE. Prevalencia de protozoos intestinales en 79 niños de 2 a 5 años de edad de un hogar infantil estatal en Circasia, Quindío. Infectio. 2010; 14(1): 31-38. DOI: 10.1016/S0123-9392(10)70090-4.

27. Botero J, Castaño A, Montoya M, Hurtado M, Ocampo N, Agudelo GM, et al. Anemia por deficiencia de hierro y su asociacion con los parasitos intestinales, en escolares y adolescentes matriculados en instituciones oficiales y privadas de Medellín. Acta Méd Colomb. 2002; 27(1): 7-14.

28. Hines DA, Balletto R. Working Paper 189: Assessment of Needs of Internally Displaced Persons in Colombia. London: Overseas Development Institute; 2002.

29. Holland CV, Taren DL, Crompton DW, Nesheim MC, Sanjur D, Barbeau I, et al. Intestinal helminthiases in relation to the socioeconomic environment of Panamanian children. Soc Sci Med. 1988; 26(2): 209-213. DOI:10.1016/0277-9536(88)90241-9.

30. Polo-Terán L, Cortés-Vecino J, Villamil-Jiménez L, Prieto E. Zoonotic nematode contamination in recreational areas of Suba, Bogotá. Rev Salud
Pública. 2007; 9(4): 550-557.

31. Kraul C. A Colombian city that's gone to the dogs. Los Angeles Times. 2010 February 19.

32. Nematian J, Nematian E, Gholamrezanezhad A, Asgari AA. Prevalence of intestinal parasitic infections and their relation with socio-economic factors and hygienic habits in Tehran primary school students. Acta Trop. 2004; 92(3): 179-186. DOI: 10.1016/j.actatropica.2004.06.010.

33. Magambo J, Zeyhle E, Wachira T. Prevalence of intestinal parasites among children in southern Sudan. East Afr Med J. 1998; 75(5): 288-290.

34. Boeke CE, Mora-Plazas M, Forero Y, Villamor E. Intestinal protozoan infections in relation to nutritional status and gastrointestinal morbidity in Colombian school children. J Trop Pediatr. 2010; 56(5): 299-306. DOI: 10.1093/tropej/fmp136.

35. Agudelo-Lopez S, Gómez-Rodríguez L, Coronado $\mathrm{X}$, Orozco A, Valencia-Gutierrez CA, RestrepoBetancur LF, et al. Prevalence of intestinal parasitism and associated factors in a village on the Colombian Atlantic Coast. Rev Salud Pública (Bogotá). 2008; 10(4): 633-642. DOI: 10.1590/ S0124-00642008000400013.

36. Murray P, Rosenthal K, Pfaller M. Intestinal and urogenital protozoa. Medical Microbiology. 7th ed. China: Elsevier Saunders; 2013. p. 714-727. 